\title{
Managing the Dollar Over Its Cycles
}

\author{
Lawrence L. Kreicher ${ }^{1} \cdot$ Robert N. McCauley $^{2}$
}

Accepted: 21 July 2021 / Published online: 17 August 2021

(C) The Author(s) 2021

\begin{abstract}
The United States has ceded to the rest of the world managing the dollar's value. For a generation, the U.S. authorities have all but withdrawn from the foreign exchange market. Yet the dollar does not float freely as a result of this handsoff U.S. policy. Instead, other authorities manage the dollar exchange rates, albeit separately. These authorities make heavier purchases of dollars in its downswings than in the upswings, damping its decline. Thus, the Fed finds that accommodative monetary policy transmits less to U.S. manufacturing and traded services, and relies on still lower rates to stimulate interest-sensitive housing and auto demand. The current U.S. dollar policy of naming and shaming surplus-running countries accumulating foreign exchange reserves does not seem to work. Three alternatives warrant consideration. First, the U.S. could reinstate its withholding tax on interest income received by non-residents and even add policy criteria to bilateral tax treaties. Second, the U.S. authorities could retaliate by selling dollars against the currencies of dollar-buying jurisdictions running chronic surpluses. However, either the withholding tax or such retaliatory foreign exchange intervention pose huge practical challenges. Third, the U.S. authorities could re-enter the foreign exchange market, making large-scale asset purchases in foreign currency when the dollar rises sharply against its average value. Such a policy would encourage private investment in U.S. traded goods and service production. The challenge is to set ex ante foreign exchange intervention rules to guide market participants' expectations, even positioning them to do the authorities' work.
\end{abstract}

Robert N. McCauley

robertneilmccauley@gmail.com

1 Associate Professor for the Practice of Economics, Duke University, NC, Durham, USA

2 Senior nonresident fellow, Global Development Policy Center, Boston University and Asociate Faculty member, Faculty of History, University of Oxford, Oxford, UK 
Keywords Dollar reserve $\cdot$ Foreign exchange market $\cdot$ International monetary system $\cdot$ Free-rider

JEL $\quad \mathrm{E} 42 \cdot \mathrm{E} 44 \cdot \mathrm{F} 3 \cdot \mathrm{F} 55 \cdot \mathrm{G} 15 \cdot \mathrm{G} 28$

\section{Introduction}

In the past year, the U.S. Treasury's semiannual currency report set the stage for a little drama. Last summer, recently retired Treasury official Sobel (2020) argued that the Treasury should not finger Switzerland as a currency manipulator. Sure, Switzerland is running a large current account surplus and accumulating foreign exchange (FX) reserves at a rapid pace. However, its policy interest rate at -75 basis points could hardly go lower. Switzerland received big safe-haven inflows in early 2020 and was not sterilising (offsetting the increase in domestic bank reserves) its intervention. ${ }^{1}$ In short, Sobel argued that the intention of the Swiss National Bank (SNB) is securing monetary stability, not protecting the traded goods sector. This recalled the argument of former Undersecretary of the Treasury Taylor (2007) that the Bush Administration should not oppose a massive $¥ 35$ trillion (circa $\$ 350$ billion) dollarbuying spree by the Ministry of Finance in 2003-04 because the Bank of Japan was simultaneously engaging in quantitative easing (i.e., increasing bank reserves as a rough counterpart to the intervention) in order to overcome deflation.

However, arguments regarding the implementation of current U.S. currency policy miss the big picture. This article steps back and asks how the dollar is being managed, what this suggests about the international monetary and financial system and which U.S. policies might make a difference.

The argument of this article proceeds in four propositions. First, U.S. authorities have ceded the management of the dollar to the rest of the world. Second, the rest of the world buys more dollars when the greenback is in a long downswing than when it is in a long upswing. Third, the international monetary and financial system can be analysed as a free-rider game in which the outcome of U.S. currency policy is irrelevant. Fourth, three policy alternatives to the current naming and shaming warrant consideration.

\section{The U.S. Authorities Have Ceded the Management of the Dollar to the Rest of the World}

In the 48 years since the start of generalised floating in 1973, the dollar traded upward in three long upswings (Fig. 1) (Engel and Hamilton, 1990; Chinn 2015). The first started with Paul Volcker's success in bringing down U.S. inflation from the

\footnotetext{
1 In its Article 4 reviews of Hong Kong and Singapore, the International Monetary Fund (IMF) accepts Hong Kong Monetary Authority's FX intervention because it is unsterilised, whereas it has questioned Singapore's FX intervention as sterilised. For unsterilised/sterilised as a distinction without a difference at very low interest rates, see McCauley and Ueda (2009).
} 


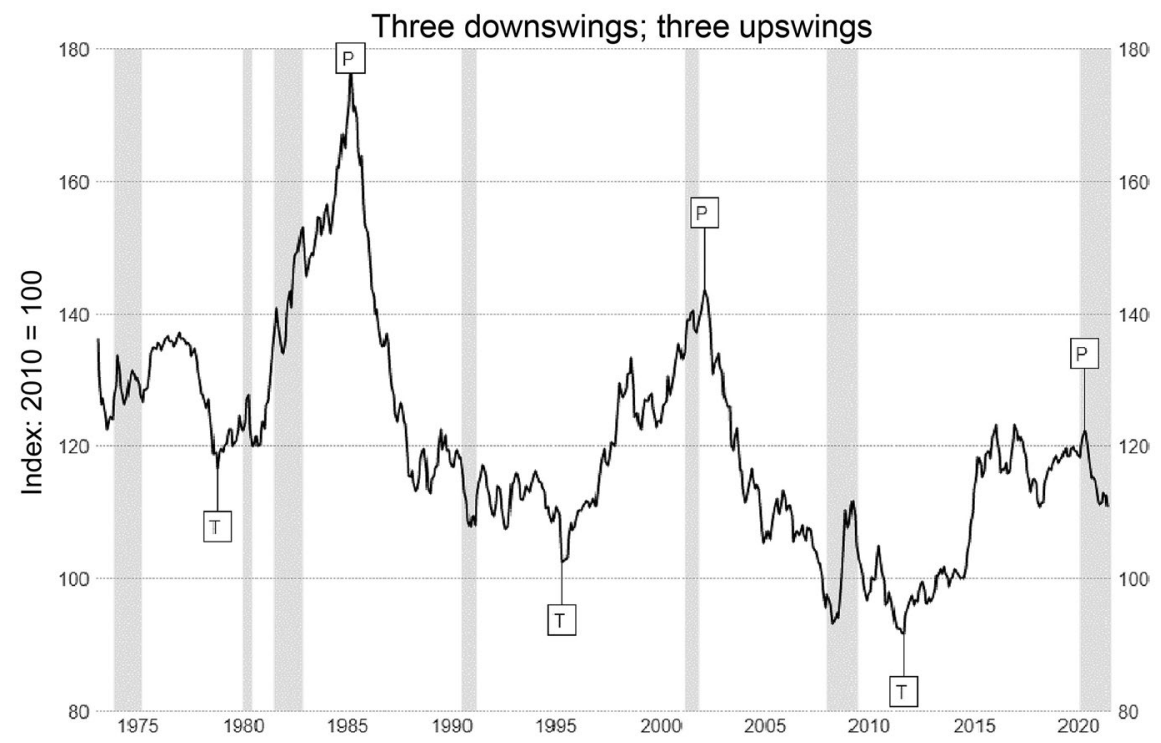

Fig. 1 US\$ effective exchange rate, 1973 to date. Source: Datastream (Refinitiv 2021); BIS narrow effective exchange rate

high levels of the late 1970s that lasted until early 1985. The second started with the confluence of a Fed tightening cycle from 1994 and Bundesbank easing cycle after the post-reunification boom that lasted into 2001. The third started around 2011 and lasted into 2020 as the Fed eased off the accelerator of large-scale asset purchases.

In this last upswing of the dollar, the U.S. authorities did not lean against the rise. This broke with precedent. In September 1985, in the face of widespread Congressional support for tariffs, the U.S. Treasury Secretary James Baker reversed the hands-off policy of Undersecretary Beryl Sprinkel. Under the latter's policy, FX intervention could only be justified by disorderly markets, such as after the attempted assassination of President Reagan (Destler and Henning, 1989). The Chicago-trained economist had drunk the Kool-Aid of Friedman (1953) and Johnson (1969). Given loose fiscal policy and tight monetary policy in the early 1980s, FX traders pushed up the dollar to its most appreciated level since 1973 without fear of being blindsided by the Treasury. ${ }^{2}$ In what became known as the Plaza Accord, Baker joined with G-5 authorities in intervention by selling dollars to bring down the dollar, which had peaked in March 1985 (Funabashi 1989; Volcker and Gyohten, 1992). Protectionist legislation receded in Congress.

\footnotetext{
2 The textbooks later ascribed the dollar's strength to the combination of loose fiscal policy and tight monetary policy, but the last leg of the dollar upwards in 1984 was hard to pin on these. In addition to the conventional policy fundamentals, the dollar got a boost in 1984 from the repeal of the withholding tax on non-resident receipts of portfolio interest (see following discussion of policy alternatives).
} 
In 2000, as the euro defied widespread predictions that it would strengthen from its start on strong portfolio inflows, the U.S. Treasury cooperated with the new European Central Bank (ECB) to sell dollars against euro to support the new currency (Fatum and Hutchison, 2002). To some extent, this intervention sought to demonstrate the capacity of the ECB, which immediately commanded less than half of the overall Eurosystem's FX reserves. In this case, the intervention episode came before the peak of the dollar in 2001. Viewed in hindsight through the prism of the long swings of the dollar, this intervention marked the last time that the U.S. authorities sold dollars to reduce their value, or at least (given the modest size of the operation) to protest against the dollar's strength vis-a-vis the euro.

The record of U.S. operations in the FX market since then is captured by the U.S. Treasury and Federal Reserve holdings of euros and yen (Fig. 2). As euro interest rates joined the near zero rate for the yen, the two series approximated flat lines. The only time that the U.S. authorities entered the FX market in the 20 years shown came in March 2011, after the Tohoku Earthquake in Japan. On that occasion, the U.S. authorities sold $\$ 1$ billion equivalent of yen against dollars, joining with the Japanese Ministry of Finance, the Bank of England and the Bank of Canada (Neely 2011). As it happened, this intervention came close to the minimum exchange rate of the dollar on an effective basis in 2011. As noted, the U.S. Treasury did not resist the dollar's strength over the next nine years.

As also noted, the rest of the world's central banks and monetary authorities showed no such reticence. Despite the ECB's long record of not intervening directly in the FX market, the somewhat shorter absence of the Japanese authorities, the shift to floating rates by major emerging market economies, and the Chinese authorities' recently reduced footprint in the FX market, officially held dollar-denominated FX reserves tended to rise year in and year out (Fig. 3). Declines happened only in periods of dollar strength in the early 1980s and in the middle of the last decade. Then,

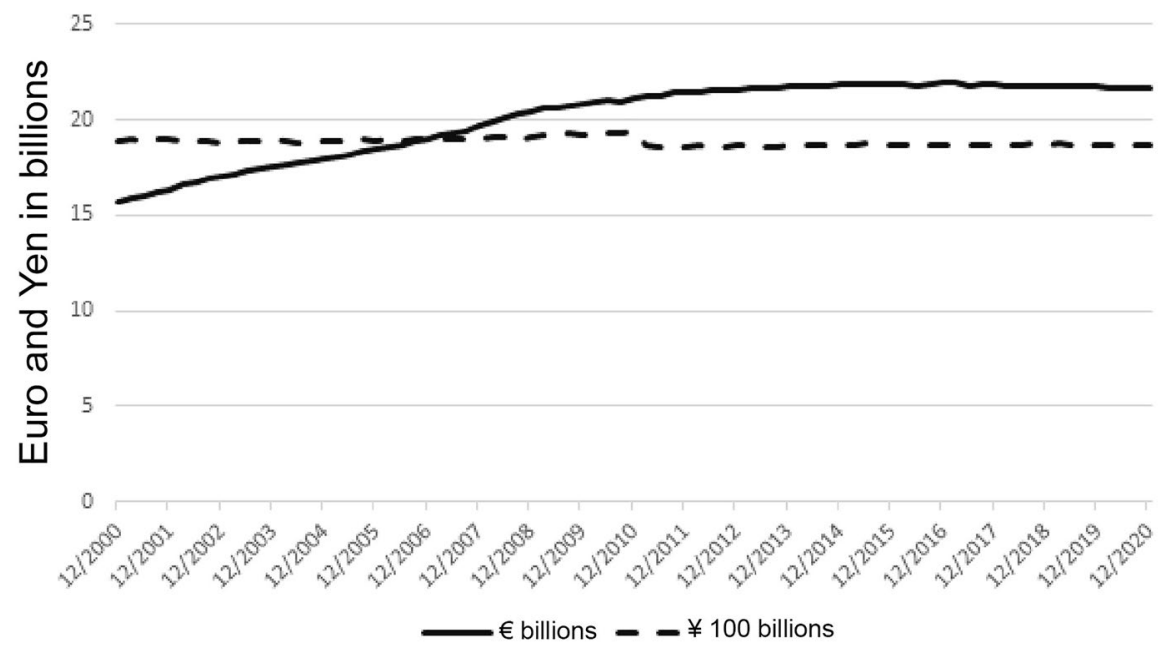

Fig. 2 U.S. official FX reserves in euro and yen. Source: Federal Reserve Bank of New York (2021); authors' calculations 


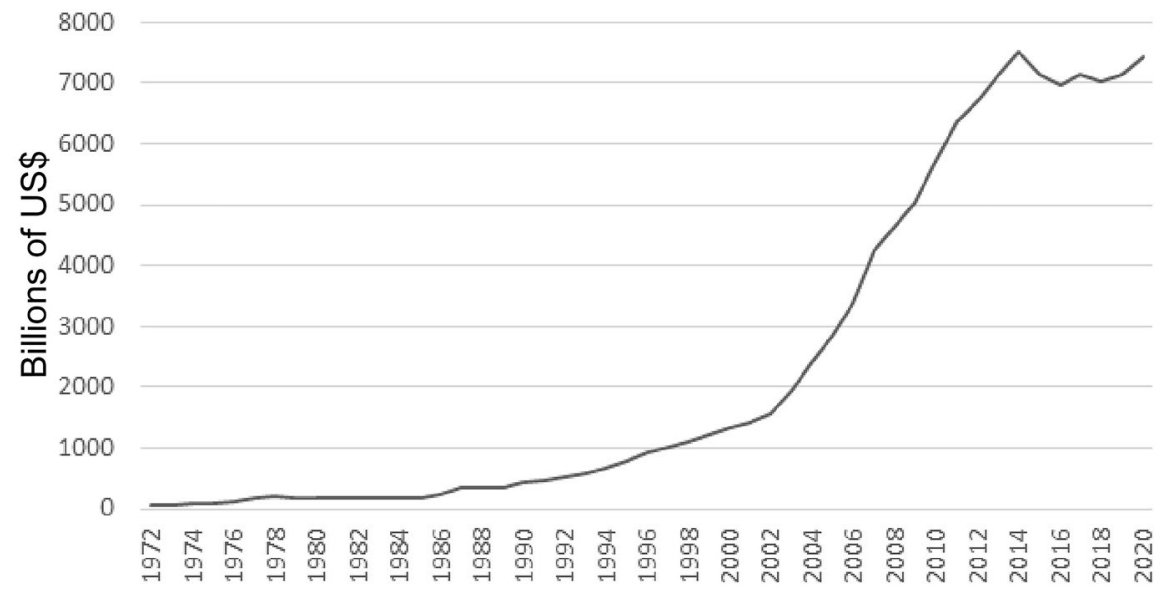

Fig. 3 Global dollar FX reserves, cumulative change since 1970, billions of US\$. Sources: IMF (2020, 2021); authors' calculations

the Chinese authorities sold dollars against renminbi to the extent that their FX reserves fell by about $\$ 1$ trillion, pacing the decline in global dollar reserves.

The cumulative growth since 1973 of $\$ 7$ trillion is similar in size to the Fed's purchase of Treasury and agency bonds since 2008. If one credits the hypothesis that the Fed's bond holdings reduced bond yields, then it is hard not to credit the hypothesis that the foreign official holdings of dollars raised the dollar's value against other currencies.

The same series, rendered as a percent of U.S. gross domestic product (GDP), better displays the declines of dollar reserve holdings during the strong dollar periods of the early 1980s and the teens of the present century (Fig. 4). The cumulative

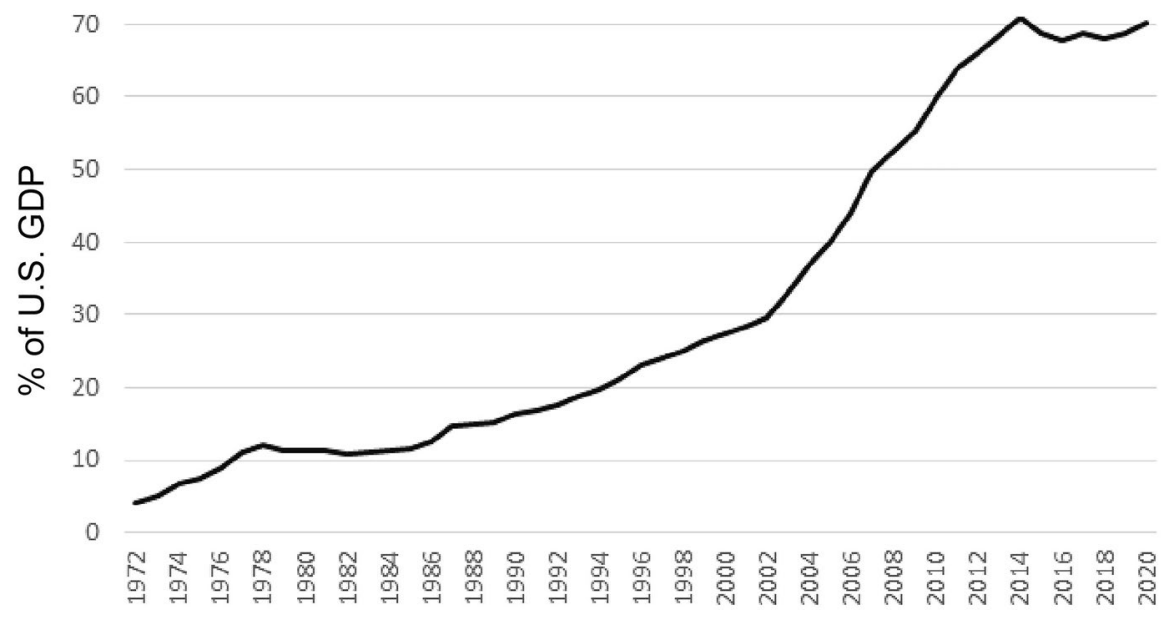

Fig. 4 Global dollar FX reserves, cumulative change since 1970, \% of U.S. GDP. Sources: IMF (2020, 2021); authors' calculations 
increase in dollar holdings by central banks since 1973 reached $70 \%$ of U.S. GDP in 2014, only to decline and then to return to that level in 2020.

Looking back, an enormous historical discontinuity deserves emphasis. The U.S. Treasury did not unilaterally disarm itself in 1933 when President Roosevelt would meet with advisors, often in his bedroom, to agree on a new higher price of gold. Nor did the U.S. authorities unilaterally disarm in 1971 when they imposed the Nixon shock, a 10\% tariff to force Deutsche mark and Japanese yen appreciation (Irwin 2013).

Despite the ideology of floating exchange rates that inspired the decisions at Camp David in August 1971 (Aliber, 2021), the U.S. Treasury subsequently continued to intervene in the FX market. The U.S. authorities did not unilaterally disarm after 1973 when Federal Reserve swap lines continued to grow in dollar terms (McCauley and Schenk, 2020). The U.S. Treasury did not unilaterally disarm in November 1978 when President Carter's Treasury Secretary Blumenthal arranged a $\$ 30$ billion support package ( $\$ 300$ billion in relation to 2021 GDP), including $\$ 15$ billion of central bank swaps, $\$ 5$ billion in IMF drawings and up to $\$ 10$ billion of the ultimately profitable Carter bonds denominated in Deutsche mark and Swiss franc.

As noted, the U.S. Treasury unilaterally disarmed itself in the big upswing of the dollar in the early 1980s under President Reagan before reversing policy at the Plaza Hotel. Then, the U.S. Treasury led the G6 in the February 1987 Louvre Accord to brake the dollar's fall. The U.S. Treasury then joined the G10 in buying dollars in August 1995, shortly after the dollar had bottomed out against the Deutsche mark and yen, "pushing on an open door" (Bank for International Settlements, 1996, p 101). Thus, the U.S. Treasury had not disarmed itself through 2000 under Presidents Bush and Clinton. However, the U.S. Treasury again disarmed itself in the dollar's upswing in the 'teens under Presidents Obama and Trump, albeit not without some characteristically impromptu verbal interventions by the latter.

\section{Dollar Reserve Accumulation Speeds Up When the Dollar Depreciates}

The prevailing view of dollar reserve accumulation is that it represents an intentional purchase of insurance against various adverse states of the world. True, it ties up a country's assets in relatively unremunerative safe assets, but its availability in the event of a sudden drying up or even reversal of international credit flows justifies the cost (or insurance premium). This is the precautionary interpretation of the motives for dollar reserve accumulation (Aizenman and Lee, 2007).

However, this interpretation comes up short when confronted with the systematic variation in the pace of dollar reserve acquisition. In particular, the precautionary account offers no prediction regarding the timing of reserve accumulation. In fact, as noted previously, the strength of accumulating dollar reserves is strongly and negatively related to the dollar's upswings and downswings.

That is, dollar reserve accumulation speeds up when the dollar is in a downswing and slows down when the dollar is in an upswing. The result applies whether one measures only the change in U.S. dollar reserves that shows up on the U.S. external balance 
sheet or estimates the change in global reserves, including those invested offshore, from IMF data. Figure 5 displays the non-subtle difference for the latter measure.

An alternative interpretation of dollar reserve accumulation sees it as the byproduct of efforts to manage exchange rates against the dollar. According to this view, the level of reserves is just an incidental result of an accumulation of other decisions, not something separately optimised. Economist Fritz Machlup likened reserve levels to Mrs. Machlup's closet (Machlup 1966; Cheung and Qian, 2009; Bird and Mandilaras, 2010), in which she stored items to get them out of the way. If dollar reserves are acquired as a by-product of efforts to resist currency appreciation in order to protect employment, profits and investment in the traded goods sector, then one would expect dollar weakness to be associated with faster dollar reserve growth.

The upshot of this asymmetry is that the transmission of accommodative U.S. monetary policy through exchange-rate depreciation is limited by the rest of the world's systematic dollar-buying. This is systematic managed floating (Frankel 2019) as experienced by the U.S. economy owing to the dollar's predominance. Therefore, for U.S. monetary policy to reach its mandated goals of full employment and price stability, the Federal Reserve must lower interest rates all the more, replacing exchange-rate induced stimulus of the traded goods sector with stimulus to housing and automobile purchases and through stock market wealth.

With this view of management of the dollar over its cycle, the next section characterises the international monetary and financial system as a free-rider game and

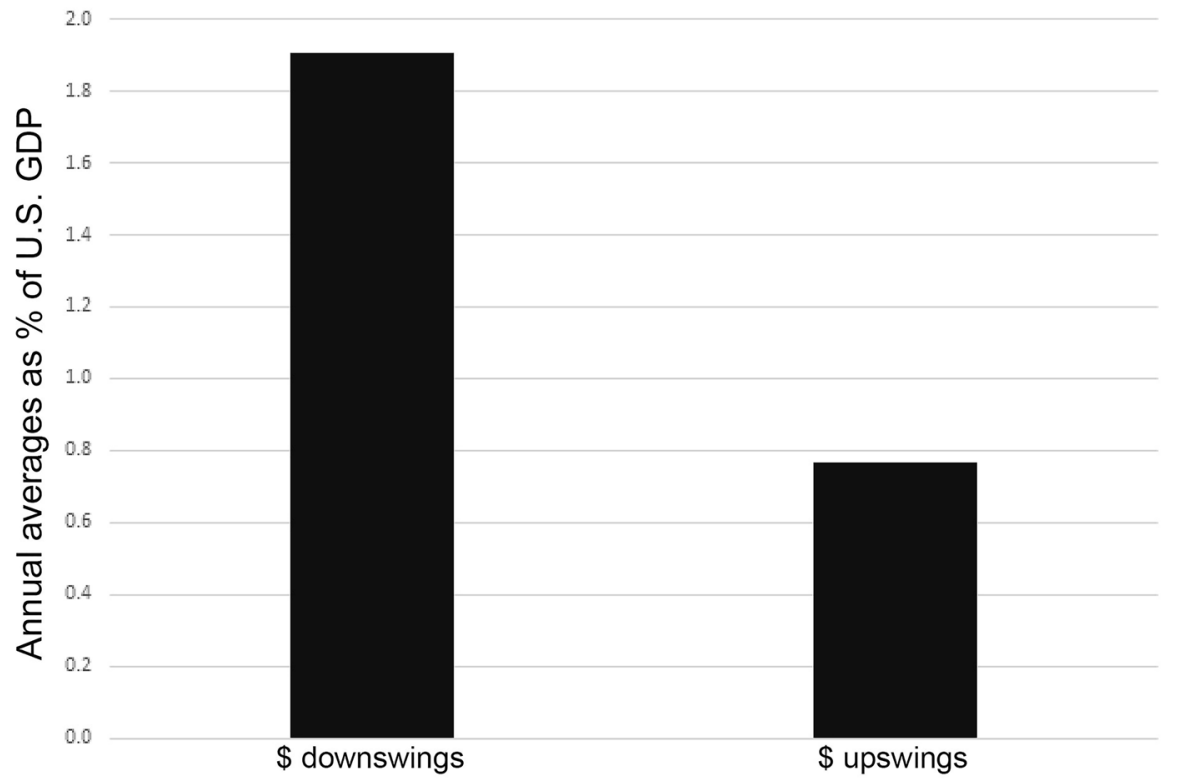

Fig. 5 Rest of world official buy 2-3 times as many dollars during dollar downswings. Source: IMF (2020, 2021), and COFER; authors' calculations based on Fig. 1 periodisation: inclusive down years = 1973-78, 1985-1994, 2002-10; up years = 1979-84, 1995-2001, 2011-19; updates Bordo and McCauley (2019) 
Table 1 International monetary system as a public good with free-riding: Status quo

\begin{tabular}{|c|c|c|c|}
\hline & & \multicolumn{2}{|l|}{ U.S. FX intervention } \\
\hline & & No & Yes \\
\hline \multirow[t]{2}{*}{ Rest of world FX intervention } & No & U.S. notion of optimum & \\
\hline & Yes & $\begin{array}{l}\text { Large FX intervention + current account surplus } \\
=>\text { "currency manipulator" designation. Smaller } \\
\text { economies intervene anyway (Olson and Zeck- } \\
\text { hauser 1966). }\end{array}$ & \\
\hline
\end{tabular}

suggests that the U.S. currency policy of naming and shaming does not change how this game is played. Then follows a consideration of three possible policy changes.

\section{The International Monetary and Financial System Can Be Analysed as a Free-Rider Game}

Table 1 presents a stylised view of the international monetary and financial system as a free-rider game. U.S. policy-makers' evident goal is a world in which all countries target inflation and allow their currencies to float freely (Table 1 northwest quadrant). In fact, the world in aggregate operates in the southwest quadrant, with the U.S. taking a hands-off approach to the dollar while the rest of the world in aggregate takes a hands-on approach.

This is a classic free-rider game, which Olson and Zeckhauser (1966) used to account for the North Atlantic Treaty Organization (NATO) carrying on despite smaller NATO members not spending their fair share on defense. The largest economy provides a public good (through disproportionate NATO defense spending or maintaining a reasonably open global trading system with N-1 determination of its exchange rate), and smaller economies improve their outcomes (by underspending on defense or by protecting their traded goods industries from unwanted appreciation).

Of course, the outcome does not satisfy the U.S. authorities or U.S. Congress. They have responded by adopting a name and shame policy. The semiannual report on trading partners' currency practices of the U.S. Treasury $(2020,2021)$ is required to name as currency manipulators those jurisdictions that accumulate reserves at a rate of over $2 \%$ of GDP per annum, while running current account surpluses over $2 \%$ of GDP per annum and trade surpluses with the U.S. The last condition is economically illiterate, spurious and manipulable, as an example readily shows.

In December 2020, the U.S. Treasury (2020) under lame-duck Secretary Mnuchin fingered Switzerland and Vietnam as currency manipulators. In the case of Switzerland, three criteria were deemed to have been met. 1) The Swiss National Bank (SNB) conducted large-scale, one-sided intervention "significantly larger than in previous periods, to resist appreciation and reduce risks of deflation" (U.S. Treasury, 2020, p. 5). Estimated net FX purchases reached $\$ 103$ billion between July 2019 and June 2020, 14\% of Swiss GDP. 2) The current account surplus reached $10.9 \%$ of Swiss 


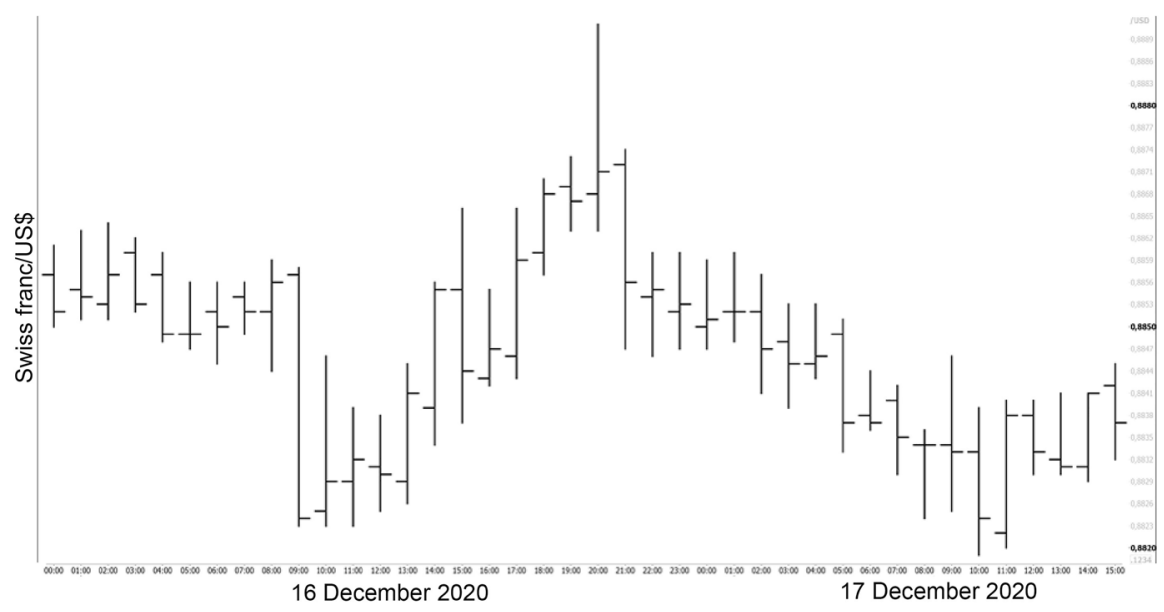

Fig. 6 Non-event: Switzerland branded a currency manipulator, 16/12/20, 13:30 GMT. Source: Datastream (Refinitiv 2021)

GDP in 2019 and 8.8\% between July 2019 and June 2020. 3) The United States' goods trade deficit "with Switzerland widened notably over the last year, reaching $\$ 49$ billion over the four quarters through June 2020, due partially to an increase in Swiss gold exports in the first half of 2020" (U.S. Treasury, 2020, p. 6).

This case aptly demonstrated the absurdity of the U.S. law's focus on bilateral balance (Gerlach et al., 2020, 2021; Kugler, 2021). Switzerland refines but does not mine gold, thus Swiss value added in gold exports is very small. Moreover, Switzerland reports an overall deficit in nonmonetary gold. ${ }^{3}$

Did the labelling hurt? Will it deter the Swiss from continuing their policy or others from running the risk of being so labelled? A proper investigation of the effects of such designations on exchange rates and credit spreads lies beyond the scope of the present work. Suffice it to say that the effect on the Swiss franc/dollar exchange rate was undetectable (Fig. 6). The Swiss franc actually depreciated against the dollar in the hours after the Treasury announcement at 13:30 GMT on 16 December 2020. Moreover, weekly data on banks' sight deposits at the SNB used as an intervention proxy by Kugler (2020) suggest little intervention.

Why this shrug by FX market participants to Goliath taking on David? Reuters (2020) described the designation as expected, which may have resulted in the designation's having had an effect spread over time, rather than concentrated in the hours after the announcement. ${ }^{4}$ It may also have been the lame-duck status of the Trump Administration along with an expectation that the designation would be reversed at

\footnotetext{
${ }^{3}$ We are indebted to Cédric Tille for pointing this out to us.

${ }^{4}$ Five months before, Sobel (2020, p. 1) led with: "Market speculation is heating up that the US Treasury, in its next semi-annual foreign exchange report, may designate Switzerland as a currency manipulator".
} 
first opportunity, as it was by Secretary Yellen's first semi-annual report in April 2021 (U.S. Treasury, 2021). ${ }^{5}$ In either case, there is no evidence here of an effective policy. The Trump Administration's designation of China as a currency manipulator was subsequently reversed after a trade deal, so its effectiveness is harder to assess.

All in all, the U.S. policy to prevent countries from intervening to hold down their currencies in the presence of large current account surpluses looks to be the opposite of President Theodore Roosevelt's advice to speak softly and carry a big stick: speak loudly and carry a small stick. What else could be done?

\section{Three Policy Options to Prevent Free-Riding Warrant Consideration}

One way or another, policy could try to make the southwest quadrant (Table 2) less rewarding, threaten counter-intervention in the hope of deterring heavy intervention or adopt a policy of U.S. intervention. That is, heavy intervention could be made less remunerative by lowering the return on dollar reserves, or deterred by threatening retaliatory intervention as proposed by Bergsten and Gagnon (2017). Alternatively, a policy of intervention keyed to the extremity of the dollar's valuation could move the game into the southeast quadrant.

The first option would be to re-impose withholding tax on U.S. interest earnings of non-residents. The Deficit Reduction Act of 1984 removed the 30\% U.S. withholding tax on most interest payments to foreigners. Note that no one called this withholding tax a capital control or capital management measure (Franson 1984; Pront and Zaitzef, 1985; Lewis 1987).

If U.S. law were to re-impose such a withholding tax (Goulder 1990), bilateral treaties could make a lower rate contingent on the recipient jurisdiction's not running a current

Table 2 International monetary system as a public good with free-riding: Alternatives

\begin{tabular}{|c|c|c|c|}
\hline & & \multicolumn{2}{|l|}{ U.S. FX intervention } \\
\hline & & No & Yes \\
\hline \multirow{2}{*}{$\begin{array}{l}\text { Rest of world } \\
\text { FX interven- } \\
\text { tion }\end{array}$} & No & U.S. notion of optimum & \\
\hline & Yes & $\begin{array}{l}\text { Re-impose withholding tax on interest } \\
\text { paid to non-residents, conditioned } \\
\text { on large intervention and current } \\
\text { account }=>\text { lower returns on U.S. dollar } \\
\text { reserves. }\end{array}$ & $\begin{array}{l}\text { "Countervailing currency inter- } \\
\text { vention": threat (Bergsten and } \\
\text { Gagnon 2017). } \\
\text { Or define U.S. FX policy to } \\
\text { purchase FX assets when \$ } \\
\text { appreciation extreme. }\end{array}$ \\
\hline
\end{tabular}

\footnotetext{
5 "It would be tempting to interpret this week's designation as a last-ditch quack of disruption by a lameduck administration. Inheriting these 'enhanced bilateral engagements' [the direct consequence of the designation], the likely next Treasury Secretary, Janet Yellen, and her colleagues may well choose to continue them. If, however, the Biden administration symbolically delists the countries without extracting any concessions right away, they'll start off by making a mockery of the Treasury's existing currency manipulation regime. Either way, the clock on Biden's first shot at currency policy is shorter. But the Trump administration now leaves behind a situation that could embarrass any Biden administration eager to soften U.S. policy on currency manipulation" (Sullivan, 2020, p. 1).
} 
account surplus and rapidly accumulating reserves. In principle, the upshot could be lower returns to surplus jurisdictions' dollar reserve holdings. This measure would fall far short of Keynes' proposal to charge interest (5-10\%!) on cumulated surpluses above a certain level (Steil 2013), but it could lower the already low returns to holding U.S. Treasury and agency securities.

However, practical difficulties abound. Recall that before the repeal of the U.S. withholding tax, U.S. multinational corporations evaded the tax by selling eurodollar bonds through Netherlands Antilles financing subsidiaries (Papke 1989). Moreover, central banks investing dollars offshore could induce more dollar bond issuance offshore by highly rated non-U.S. obligors. McCauley (2020) already estimated dollar reserves held offshore at $\$ 1$ trillion.

While perhaps appealing in principle, this option presents huge practical problems. The next two options threaten a tit-for-tat or a rules-based move to the southeast quadrant.

The U.S. could threaten to counter dollar accumulation by the rest of the world with dollar sales against the same currency. In terms of Table 2, countervailing currency intervention, as dubbed by Bergsten and Gagnon (2017) and Bergsten (2019), would threaten a move to the uncooperative southeast quadrant in the hope of inducing a move to the northwest quadrant. The result would depend on the credibility of the threat and the likelihood of miscalculation. If the threat is credible, free-riding (from the U.S. perspective) would be deterred, and the system might move to the northwest quadrant.

If the threat proves not credible, countervailing currency intervention would exactly offset large dollar reserve accumulation, given large current account surpluses and ample reserves. Then the system would move to the southeast quadrant, a real currency war, with unforeseeable FX market effects. However, unlike tariffs, which can be so popular as to make their removal politically difficult (Irwin 2013), if surplus countries cease to accumulate dollars, then the U.S. would cease countervailing currency intervention.

Once again, practical problems abound. ${ }^{6}$ Three come readily to mind. Central banks could evade this bilateral approach by understating their dollar holdings and investing in dollar instruments offshore, which as noted already accounted for $\$ 1$ trillion of the $\$ 7$ trillion in dollar reserves in 2017 (McCauley 2020). They could also evade by buying dollars against euros and other key currencies forward in the unobservable over-the-counter market. Finally, they could also evade by buying Hong Kong dollars, Canadian dollars, Mexican pesos or other currencies that co-move with the dollar against the euro (Ito and McCauley, 2019; Ilzetzki et al., 2019).

A better approach might be to eschew such bilateralism and counter all large intervention by large surplus countries with intervention. Ideally, the IMF membership could decide to police large chronic surpluses recycled through the government balance sheet. Then the IMF could perform the countervailing intervention.

\footnotetext{
${ }^{6}$ Sobel (2019) cited the potential for intense financial instability as authorities slug it out, emphasized the capacity of the counterparty country to offset or sterilise U.S. purchase of its domestic currency, and worries about the consequences of the Federal Reserve not joining the U.S. Treasury in such a policy.
} 
However, the record of the IMF's surveillance of global imbalances suggests that its members would not reach such an agreement. ${ }^{7}$

Absent such a club approach, the U.S. authorities could carry out the countervailing currency intervention on a fully multilateral basis. Countervailing intervention would be blind to the investment of FX reserves in the dollar, the euro or other key currencies (Ito and McCauley, 2020; Iancu et al., 2020). However, even this fully multilateral approach would face the practical problem of recycling surpluses through state-owned banks or pension funds.

This brings us to the third option of the U.S. authorities intervening to lean against extreme valuations of the dollar. Given the previous finding that the rest of the world steps up its intervention when the dollar is in a long downswing, the key change here would be the U.S. selling dollars and buying foreign currencies when the dollar is particularly strong. The definition of particularly strong is of course problematic. Ideally, one would have a rule for intervention (Bordo and Taylor, 2017). In the limit, market participants could anticipate the intervention and it might become unnecessary to carry out.

Large-scale asset purchases have raised many observers' assessments of the power of portfolio balance effects. The conventional wisdom that discounted the efficacy of FX interventions drew conclusions from operations of a scale that were rounding error in recent bond-buying by central banks. Moreover, the model for sterilised intervention at the time had a central bank ultimately selling bonds in one currency and buying bonds in another currency, leaving the effect dependent on the lack of substitutability across major bond markets. In fact, most reserve accumulation in recent years was funded with short-term instruments, whereas the FX is typically invested in bonds. This practice makes reserve accumulation akin to large scale asset (bond) purchases at the global level, removing duration from private investors' hands (McCauley, 2017).

It is true that U.S. FX intervention does not have a sterling record, and often served as a means to temporise and tweak unsustainable policy (Bordo et al., 2015). That said, there were episodes like the $\$ 30$ billion package in late 1978 that well anticipated substantial policy changes for the better. Part of the criticism of the U.S. record of FX intervention is that it was discretionary and ad hoc, even sometimes coming on both sides of the market in a short period of time.

This last option, conceived as disciplined, ex ante and rule-bound, doubtless would strike many as pie in the sky. Yet the Reserve Bank of Australia has a record of intervening in precisely such a manner. Figure 7 summarises 20 years of its FX intervention, which has the character of leaning against, or at least protesting, extreme valuations. Could this be reverse engineered so that some rule-based approach can be taken by the U.S. authorities?

Intervention to cap dollar strength would entail purchases of foreign currency that would add to the tiny U.S. FX reserves, as seen here. Such purchases would

\footnotetext{
7 In the absence of such a fully multilateral approach, a coalition could employ the Bank for International Settlements (BIS) to perform countervailing intervention against recycling chronic large surpluses through government balance sheets. However, the BIS statutes appear to preclude operations in a given market without the consent of the respective central bank.
} 


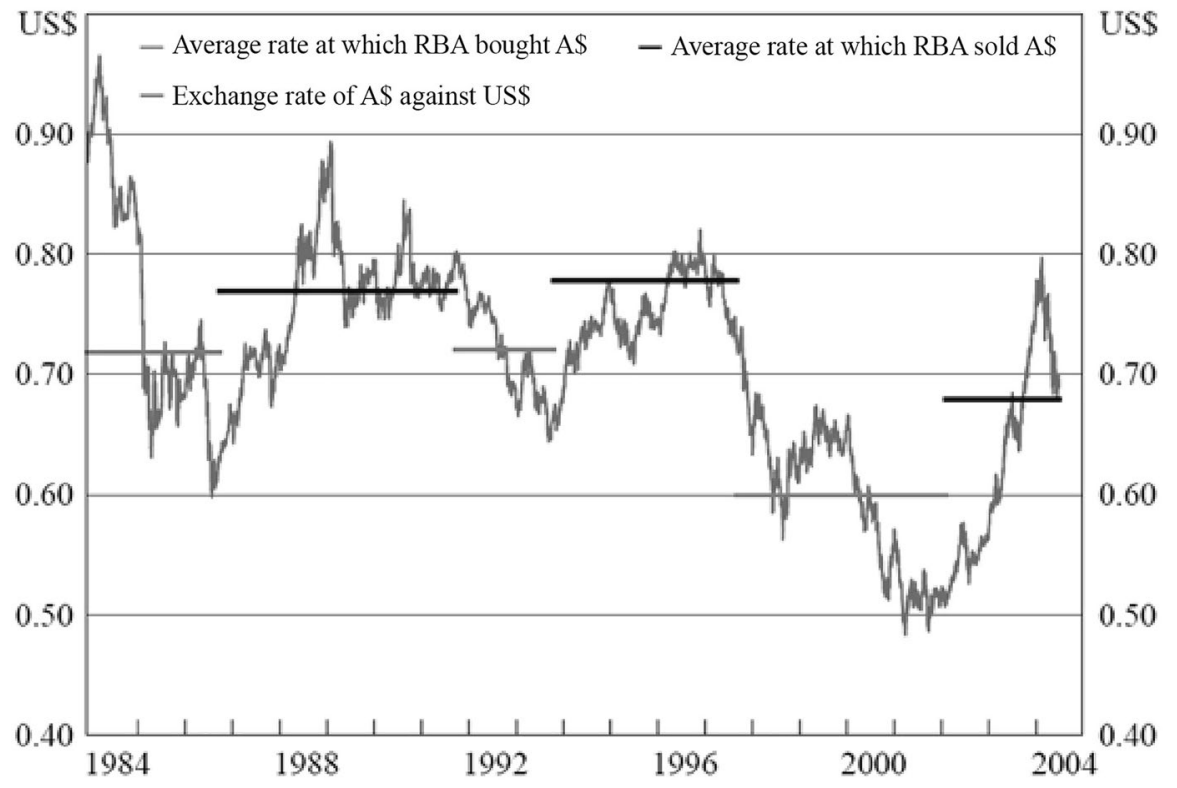

Fig. 7 Australian dollar/U.S. dollar exchange rate and Reserve Bank of Australia (RBA) average transaction rate (bought (grey line) versus sold (dark line)). Source: Becker and Sinclair (2004, p.13)

equip the U.S. authorities with the wherewithal to sell off foreign currency assets in the event of extreme under-valuation of the dollar. It would also provide the Federal Reserve with the wherewithal to do FX lender-of-last-resort operations for U.S. banks, the largest of which now have substantial foreign currency books.

\section{Conclusion}

The U.S. has ceded to the rest of the world managing the dollar's value. For their part, the U.S. authorities have all but withdrawn from the FX market for a generation. Despite this hands-off U.S. policy, other authorities have adopted a decidedly hands-on approach to the dollar. Thus, the U.S. dollar does not freely float. Rather, authorities elsewhere manage many of its exchange rates, albeit individually. The record shows that authorities outside the U.S. buy many more dollars during downswings than during upswings. The Federal Reserve found that accommodative monetary policy transmits less to U.S. manufacturing and traded services, and so relies on still lower rates to stimulate interest-sensitive housing and auto demand.

Current U.S. dollar policy does not work. U.S. policy names and shames surplus-running countries accumulating FX reserves to little effect. Three alternatives warrant consideration. First, the U.S. could reinstate its withholding tax on 
interest income received by non-residents and even add policy criteria to bilateral tax treaties. Second, the U.S. authorities could retaliate by buying the currencies of dollar-buying jurisdictions running chronic surpluses. However, the withholding tax and retaliatory intervention pose huge practical challenges. Third, the U.S. authorities could re-enter the FX market, doing large-scale asset purchases in foreign currency when the dollar rises sharply against its average value. Such a policy would encourage private investment in U.S. traded goods and service production. The challenge is to set ex ante $\mathrm{FX}$ intervention rules to guide market participants' expectations, in the best case positioning them to do the authorities' work.

Acknowledgements The authors thank Robert Aliber, Menzie Chinn, Joseph Gagnon, Fred Hickman, Hiroyuki Ito, Catherine Schenk, Mark Sobel and Cédric Tille for discussion and the editor. All faults and judgements remain the authors'.

Open Access This article is licensed under a Creative Commons Attribution 4.0 International License, which permits use, sharing, adaptation, distribution and reproduction in any medium or format, as long as you give appropriate credit to the original author(s) and the source, provide a link to the Creative Commons licence, and indicate if changes were made. The images or other third party material in this article are included in the article's Creative Commons licence, unless indicated otherwise in a credit line to the material. If material is not included in the article's Creative Commons licence and your intended use is not permitted by statutory regulation or exceeds the permitted use, you will need to obtain permission directly from the copyright holder. To view a copy of this licence, visit http://creativecommons.org/ licenses/by/4.0/.

\section{References}

Aizenman, J., \& Lee, J. (2007). International reserves: Precautionary versus mercantilist views, theory and evidence. Open Economies Review, 18(2), 191-214.

Aliber, R. (2021). Auric Goldfinger, Henry Morgenthau, and Camp David: August 1971. Atlantic Economic Journal, 49(2): Springer.

Bank for International Settlements. (1996). 66th Annual Report, Basel. https://www.bis.org/publ/arpdf/ archive/ar1996_en.pdf

Becker, C., \& Sinclair, M. (2004). Profitability of Reserve Bank foreign exchange operations: Twenty years after the float. Research Discussion Paper 2004-o6. https://www.rba.gov.au/publications/rdp/ 2004/pdf/rdp2004-06.pdf

Bergsten, F. (2019). Commerce Department's proposal to curb currency manipulation uses the wrong tool. Washington, DC Peterson Institute for International Economics, Trade and investment Policy Watch. https://www.piie.com/blogs/trade-investment-policy-watch/commerce-departments-proposal-curbcurrency-manipulation-uses

Bergsten, C. F., \& Gagnon, J. E. (2017). Currency conflict and trade policy. Peterson Institute of International Economics, Columbia University Press.

Bird, G., \& Mandilaras, A. (2010). Revisiting Mrs. Machlup's wardrobe: The accumulation of international reserves, 1992-2001. Applied Economics Letters, 17(5), 467-471.

Bordo, M., \& McCauley, R. (2019). Triffin: Dilemma or myth. IMF Economic Review, 67(4), 824-851.

Bordo, M., Humpage, O., \& Schwartz, A. (2015). Strained relations: US foreign exchange operations and monetary policy in the twentieth century. Chicago: University of Chicago Press.

Bordo, M., \& Taylor, J. (2017). Rules for international monetary stability. Stanford Hoover Institution Press.

Cheung, Y.-W., \& Qian, X. (2009). Hoarding of international reserves: Mrs Machlup's wardrobe and the Joneses. Review of International Economics, 17(4), 824-843. 
Chinn, M. (2015). How much more dollar appreciation?. Econbrowser. http://econbrowser.com/archives/ 2015/04/how-much-more-dollar-appreciation

Destler, I., \& Henning, R. (1989). Dollar politics: Exchange rate policymaking in the United States. Washington, DC: Institute for International Economics.

Engel, C., \& Hamilton, J. D. (1990). Long swings in the dollar: Are they in the data and do markets know it? American Economic Review, 80(4), 689-713.

Fatum, R., \& Hutchison, M. (2002). ECB foreign exchange intervention and the euro: Institutional framework, news, and intervention. Open Economies Review, 13(4), 413-425.

Federal Reserve Bank of New York (2021). Treasury and Federal Reserve foreign exchange operations: quarterly reports, 2001-2021. https://www.newyorkfed.org/markets/quar_reports

Frankel, J. (2019). Systematic managed floating. Open Economies Review, 30(2), 255-295.

Franson, M. (1984). Repeal of the thirty percent withholding tax on portfolio interest paid to foreign investors. Northwestern Journal of International Law \& Business, 6(3), 930-978.

Friedman, M. (1953). The case for flexible exchange rates. In: Essays in positive economics, Chicago: University of Chicago Press.

Funabashi, Y. (1989). Managing the dollar: From the Plaza to the Louvre. Washington, DC: Peterson Institute for International Economics.

Gerlach, S., Lengwiler, Y., \& Wyplosz, C. (2020). The SNB is not a currency manipulator. The SNB Observatory. https://snb-observatory.ch/wp-content/uploads/2020/12/2020-12-17-currency-manipulation.pdf

Gerlach, S., Lengwiler, Y., \& Wyplosz, C. (2021). The SNB is not a currency manipulator: An update. The SNB Observatory. https://snb-observatory.ch/wp-content/uploads/2021/01/SNB-ObservatoryReport-1-Update-Currency-Manipulation.pdf

Goulder, L. (1990). Implications of introducing U.S. withholding taxes on foreigners' interest income. In: L. Summers (Ed.), Tax Policy and the Economy: Volume 4, Cambridge, MA: The MIT Press.

Iancu, A., Anderson, G., Ando, S., Boswell, E., Gamba, A., Hakobyan, S., Lusinyan, L., Meads, N., \& Wu, Y. (2020). Reserve currencies in an evolving international monetary system, IMF Departmental Paper 2020/002. https://www.imf.org/en/Publications/Departmental-Papers-Policy-Papers/Issues/ 2020/11/17/Reserve-Currencies-in-an-Evolving-International-Monetary-System-49864

Ilzetzki, E., Reinhart, C., \& Rogoff, K. (2019). Exchange rate arrangements entering the 21st Century: Which anchor will hold? Quarterly Journal of Economics, 134(2), 599-646.

International Monetary Fund. (2020). Annual Reports, various years, 1970-2020. https://www.imf.org/en/ Publications/AREB

International Monetary Fund. (2021). Currency Composition of Official Foreign Exchange Reserves (COFER). https://data.imf.org/?sk=E6A5F467-C14B-4AA8-9F6D-5A09EC4E62A4

Irwin, D. (2013). The Nixon shock after 40 years: The import surcharge revisited. World Trade Review, 12(1), 29-56.

Ito, H., \& McCauley, R. (2019). A key currency view of global imbalances. Journal of International Money and Finance, 94, 97-115.

Ito, H., \& McCauley, R. (2020). Currency composition of foreign exchange reserves. Journal of International Money and Finance, 102. https://doi.org/10.1016/j.jimonfin.2019.102104

Johnson, H. (1969). The case for flexible exchange rates, 1969. Federal Reserve Bank of St. Louis Review, 51, 12-24. https://files.stlouisfed.org/files/htdocs/publications/review/69/06/Flexible_Jun1969.pdf

Kugler, P. (2020). The short-run impact of SNB sight deposits on exchange rates: Results from weekly data, 2015 - 2018. WWZ Working Paper 2020/04, University of Basel. https://edoc.unibas.ch/ 76180/1/2020_04_rev_SNB\%20Giro\%20and\%20exchange\%20rates.pdf

Kugler, P. (2021). The blame game: Das US-Handelsbilanzdefizit und der Franken-Dollar Kurs, Basel University, WWZ Faculty Blog. https://unibaswwzfaculty.blog/2021/01/05/the-blame-game-das-ushandelsbilanzdefizit-und-der-franken-dollar-kurs/

Lewis, M. (1987). Foreign recipients of U.S. income, and tax withheld, 1985. Statistics of Income Bulletin, 7(2), 27-43.

Machlup, F. (1966). The need for monetary reserves. Banca Nazionale del Lavoro, Quarterly Review, 78, 58-75.

McCauley, R. (2017). Global bond market spillovers from monetary policy and reserve management. In A. Ghosh \& M. Qureshi (Eds.), From Great Depression to Great Recession: The elusive quest for international policy cooperation (pp. 147-66). Washington, DC: IMF.

McCauley, R. (2020). Safe assets and reserve management. In J. Bjorheim (Ed.), Asset management at central banks and monetary authorities (pp. 131-150). Cham, Switzerland: Springer, pp. 131-150. 
McCauley, R. \& Schenk, C. (2020). Central bank swaps then and now: Swaps and dollar liquidity in the 1960s. BIS Working Papers no 851. https://www.bis.org/publ/work851.pdf

McCauley, R. \& Ueda, K. (2009). Government debt management at low interest rates. BIS Quarterly Review, 35-51. https://www.bis.org/publ/qtrpdf/r_qt0906e.pdf

Olson, M., \& Zeckhauser, R. (1966). An economic theory of alliances. Review of Economics and Statistics, 48(3), 266-279.

Neely, C. (2011). A foreign exchange intervention in an era of restraint. Federal Reserve Bank of St. Louis Review, 93(5), 303-324.

Papke, L. (1989). International differences in capital taxation and corporate borrowing behavior: Evidence from the US withholding tax. NBER Working Paper no 3129. https://www.nber.org/system/files/working_papers/ w3129/w3129.pdf

Pront, P., \& Zaitzef, R. (1985). Repeal of the United States withholding tax on interest paid to foreigners. International Tax and Business Lawyer, 3, 191-248.

Refinitiv. (2021). Datastream. Available at: https://solutions.refinitiv.com/datastream-macroeconomic-analysis/? utm_content=Product $\% 20$ Name-US-AMER-B-EN-BMM\&utm_medium =cpc\&utm_source=bing\& utm_campaign $=434508 \_$PaidSearchEN\&elqCampaignId $=13781 \&$ utm_term $=+$ datastream \&\&msclkid $=$ $63368122 \mathrm{cc} 841554 \mathrm{~d} 0 \mathrm{~b} 7 \mathrm{e} 1 \mathrm{c} 433 \mathrm{a} 92 \mathrm{f} 81 \& \mathrm{gclid}=63368122 \mathrm{cc} 841554 \mathrm{~d} 0 \mathrm{~b} 7 \mathrm{e} 1 \mathrm{c} 433 \mathrm{a} 92 \mathrm{f} 81 \& \mathrm{gclsrc}=3 \mathrm{p} . \mathrm{ds}$

Reuters. (2020). U.S. Treasury labels Switzerland, Vietnam as currency manipulators. https://www.reuters. com/world/china/us-treasury-labels- switzerland-vietnam-currency-manipulators-2020-12-16/

Sobel, M. (2019). Countervailing intervention: Undesirable and unworkable. OMFIF Blog. https://www.omfif. org/2019/07/currency-action-is-a-distraction/

Sobel, M. (2020). Next US Treasury report should not designate Swiss franc. OMFIF Blog. https://www. omfif.org/2020/07/next-us-treasury-report-should-not-designate-swiss-franc/

Steil, B. (2013). The battle of Bretton Woods. Princeton: Princeton University Press for the Council on Foreign Relations.

Sullivan, J. (2020). Trump leaves Biden Administration a parting gift in currency wars, Foreign Policy. https:// foreignpolicy.com/2020/12/18/trump-leaves-biden-administration-a-parting-gift-in-currency-wars/

Taylor, J. (2007). Global financial warriors: The untold story of international finance in the post-9/11 world. New York: W.W. Norton.

U.S. Treasury, Office of International Affairs. (2020). Macroeconomic and foreign exchange policies of major trading partners of the United States, December semi-annual report. https://home.treasury. gov/system/files/206/December-2020-FX-Report-FINAL.pdf

U.S. Treasury, Office of International Affairs. (2021). Macroeconomic and foreign exchange policies of major trading partners of the United States, April semi-annual report. https://home.treasury.gov/ system/files/206/April_2021_FX_Report_FINAL.pdf

Volcker, P., \& Gyohten, T. (1992). Changing fortunes: The world's money and the threat to American leadership. New York: Times Books.

Publisher's Note Springer Nature remains neutral with regard to jurisdictional claims in published maps and institutional affiliations. 